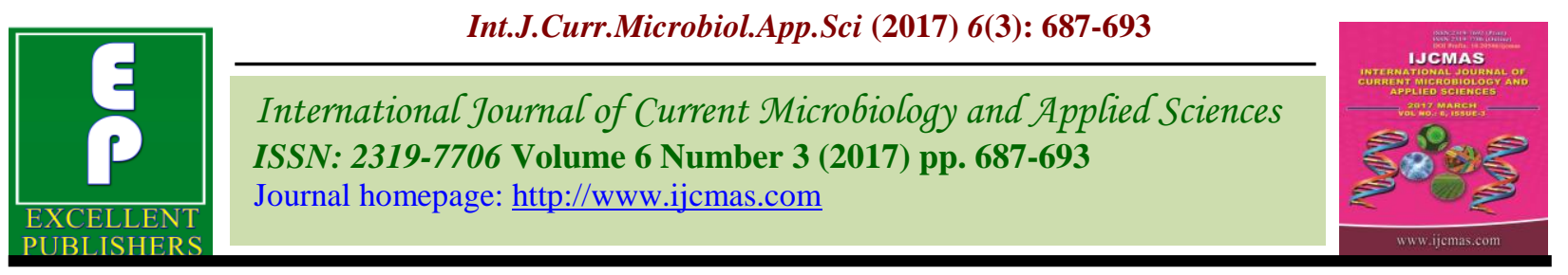

Original Research Article

https://doi.org/10.20546/ijcmas.2017.603.079

\title{
Comparison of Staining of Keratin Pearl and Individual Cell Keratin in Oral Squamous Cell Carcinoma by Modified Papanicolaou, Modified Mallory's and Hematoxylin and Eosin Stain
}

\author{
Santhosh Kumar Caliaperoumal $^{1^{*}}$, Sudhakar Srinivasan ${ }^{2}$ and \\ Meer Ahmed Ibrahim Munshi ${ }^{3}$ \\ ${ }^{1}$ Department of Dentistry, Vinayaka Mission's Medical college and Hospital, \\ Karaikal, Puducherry, India \\ ${ }^{2}$ Department of Dentistry, Karpagam Medical College and hospital, Coimbatore, \\ Tamil nadu, India \\ ${ }^{3}$ Department of Oral surgery, Sri Ramakrishna dental college and hospital, Coimbatore, \\ Tamilnadu, India \\ *Corresponding author
}

\section{A B S T R A C T}

\section{Keywords}

Squamous cell carcinoma (SCC),

Keratin Pearl (KP),

Individual cell Keratin

(ICK), Modified

Papanicolou (PAP)

stain, Hematoxylin and

Eosin (H\&E) stain.

Article Info

Accepted:

15 February 2017

Available Online:

10 March 2017
Observation of Keratin pearl (KP) and individual cell keratin (ICK) is one of the criteria in grading oral squamous cell carcinoma (SCC). The aim of the study was to evaluate and compare the distinct staining and identification of KP and ICK by routine Hematoxylin and Eosin (H\&E) stain Modified Mallory's and Modified Papanicolaou Stain. A total number of 38 paraffin embedded tissues of known cases of well-differentiated and moderately-differentiated SCC were taken and 3 sections of 4-5 micron thickness from each block were cut and stained with H\&E stain, Modified Mallory's and modified Papanicolou stain. The KP and ICK were distinctly and clearly stained by modified Papanicolou, modified Mallory's stain compared to H\&E stain. The positive staining of KP and ICK by modified Papanicolou stain was statistically significant than modified Mallory's and H\&E stain at $\mathrm{P}=0.033$ and $\mathrm{P}=0.001$. Based on our findings we conclude that the efficacy of distinct identification of KP and ICK in oral SCC by modified Papanicolou stain is better than modified Mallory's stain and H\&E stain. So it can be used as an adjuvant in case of oral SCC.

\section{Introduction}

Oral cancer is one of the most common malignant tumours. Oral squamous cell carcinoma constitutes more than $90 \%$ of the oral cancer. It is mostly reported at late stage in Indian scenario (Neville et al., 2002; Shafer et al., 1993; Parija, 1991; Pindborg et al., 1990). The prognosis and treatment outcome is proportional to differentiation level of OSCC. A well differentiated OSCC has better prognosis (Harrison et al., 1999; Kumar et al., 
2004). One of the important parameter in grading is keratin pearl and individual cell keratin observation (Neville et al., 2009). The quality and quantity of keratin synthesis reflects the differentiation level of normal and abnormal epithelial cells (Coulombe et al., 1990; Schweizer et al., 1983; Nagle et al., 1983; Rothman et al., 1954).

The identification and staining of individual cell keratin and keratin pearl is important in histopathological grading and diagnosis of oral squamous cell carcinoma (Neville et al., 2002; Shafer et al., 1993; Parija, 1991; Pindborg et al., 1990).

So we studied and compared the identification and staining of individual cell keratin and keratin pearl in oral squamous cell carcinoma by routine Hematoxylin \& Eosin stain modified Papanicolaou stain and modified Mallory's stain (Ayoub et al., 1963).

\section{Materials and Methods}

A total numbers of 38 cases of OSCC were taken for study. The histo-pathologically diagnosed cases of oral squamous cell carcinomas from were retrieved from pathology department for the study group. The only criteria selected for inclusion is that there should be enough tissue material in paraffin blocks. From each block three serial sections were made of 5-micron thickness and stained by routine $\mathrm{H} \& \mathrm{E}$ stain, modified Mallory's stain and modified Papanicolou stain for keratin.

The staining protocol suggested by Richard P. Elzay (Elzay et al., 1983) for modified Papanicolou stain and Ayoub-shklar for modified Mallory's stain was followed for all the cases.

The criteria of clear identification of keratin pearl and individual cell keratin were analyzed with an aim to identify and compare the better staining of keratin by H\&E stain and modified Papanicolou stain and modified Mallory's stain in oral squamous cell carcinoma.

The data was subjected to statistical analysis by SPSS software version 16 .

\section{Results and Discussion}

The study included 38 cases of oral SCC which were stained by $\mathrm{H} \& \mathrm{E}$, modified mallory's and modified Papanicolou stain. These stained sections were evaluated and compared for distinct and clear identification of KP and ICK.

The modified papanicolou stain showed a positive staining of KP in $30(78.9 \%)$ cases, modified Mallory's stain showed positivity in $28(73.7 \%$ ) cases H\&E stain showed positive staining in $20(52.6 \%$ ) cases (Table-1, Graph1).

The positive staining of KP was statistically significant for all stains with chi-square value of 6.821, $p$ value of $p<0.05$ ( $p=0.033$ ) (Table3). This Indicates there was a statistically significant positive staining of KP by modified Papanicolou stain than modified Mallory and H\&E stain in oral SCC.

The modified PAP stain showed a positive staining of ICK in $30(78.9 \%)$ cases and Modified Mallory's stain showed positivety in $23(60.53 \%)$ cases whereas H\&E stain showed positive staining in $13(34.2 \%)$ cases (Table-2, Graph-2).

The positive staining of ICK was statistically significant for modified PAP than H\&E with chi-square value of $15.761, \mathrm{p}$ value of $\mathrm{p}$ $=0.001$ (Table-4). This Indicates there was a statistically significant positive staining of ICK by modified Papanicolou than modified Mallory's and H\&E stain in oral SCC. 
In squamous cell carcinoma level of keratin synthesis is directly proportional to the level of differentiation which has an association with prognosis. Hence the study was taken up with an aim to compare clear and better identification keratin pearl and individual cell keratinization in the oral squamous cell carcinoma with $H \& E$ and modified
Papanicolou and modified Mallory's stain. The demonstration of keratin pearl was significantly positive at $p<0.05$ in Modified Papanicolaou stain than modified Mallory's stain and H\&E stain. This can be utilized for the easy confirmation of diagnosis a welldifferentiated SCC.

Table.1 Keratin Pearl staining in oral squamous cell carcinoma by hematoxylin and eosin stain, modified Papanicolaou stain and modified Mallory's stain

\begin{tabular}{|l|c|c|c|}
\hline & H\&E Stain & Modified Papanicolou Stain & Modified Mallory's Stain \\
\hline Positive Staininig & 20 & 30 & 28 \\
\hline Negative Staining & 18 & 8 & 10 \\
\hline TOTAL & 38 & 38 & 38 \\
\hline
\end{tabular}

Table.2 Individual cell Keratin staining in oral squamous cell carcinoma by hematoxylin and eosin stain, modified Papanicolaou stain and modified Mallory's stain

\begin{tabular}{|l|c|c|c|}
\hline & H\&E Stain & Modified Papanicolou Stain & Modified Mallory's Stain \\
\hline Positive Staininig & 13 & 30 & 23 \\
\hline Negative Staining & 25 & 8 & 15 \\
\hline TOTAL & 38 & 38 & 38 \\
\hline
\end{tabular}

Table.3 Statistical analysis of Keratin Pearl staining in oral squamous cell carcinoma by hematoxylin and eosin stain, modified Papanicolaou stain and modified Mallory's stain

\begin{tabular}{|c|c|c|c|}
\hline Count & H \& E Stain & $\begin{array}{l}\text { Modified papanicolou } \\
\text { stain }\end{array}$ & $\begin{array}{c}\text { Modified Mallory } \\
\text { Stain }\end{array}$ \\
\hline Positive & 20 & 30 & 28 \\
\hline Negative & 18 & 8 & 10 \\
\hline Total & 38 & 38 & 38 \\
\hline
\end{tabular}

a. 0 cells $(.0 \%)$ have expected count less than 5 . The minimum expected count is 12.00 . 
Table.4 Individual cell Keratin staining in oral squamous cell carcinoma by hematoxylin and eosin stain, modified Papanicolaou stain and modified Mallory’s stain

\begin{tabular}{|r|r|r|rr|}
\hline & & & \multicolumn{2}{|c|}{$\begin{array}{c}\text { Modified Mallory } \\
\text { Stain }\end{array}$} \\
& H \& E Stain & Modified papanicolou stain & 23 \\
& 13 & 30 & 15 \\
Total & 25 & 8 & 38 \\
\hline
\end{tabular}

a. 0 cells $(.0 \%)$ have expected count less than 5 . The minimum expected count is 16.00 .

Fig.1 Keratin pearl staining in oral squamous cell carcinoma by H\&E (a) and Modified Papanicolaou (b) and Modified Mallory's (c) stain
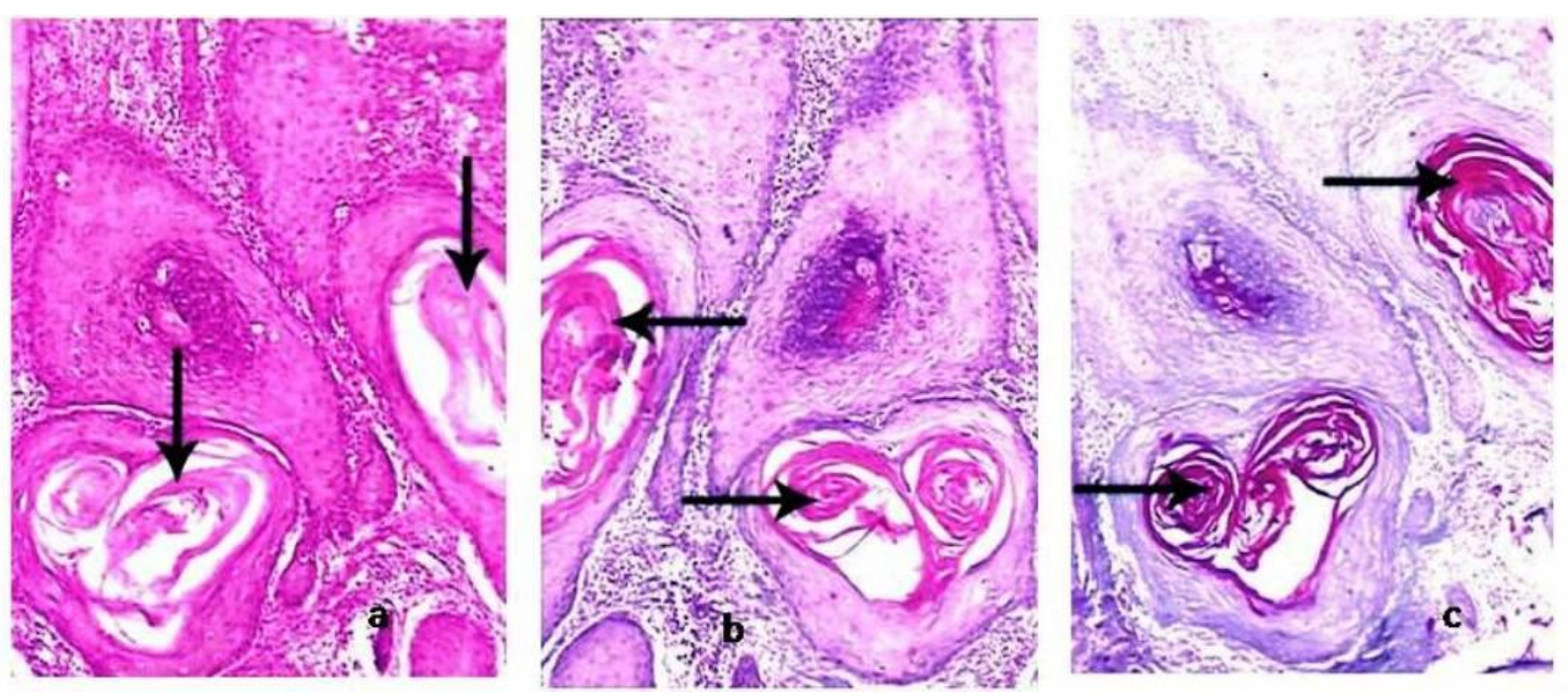
Fig.2 Individual Cell Keratin staining in oral squamous cell carcinoma by H\&E (a) Modified Papanicolaou (b) and Modified Mallory's (c) stain
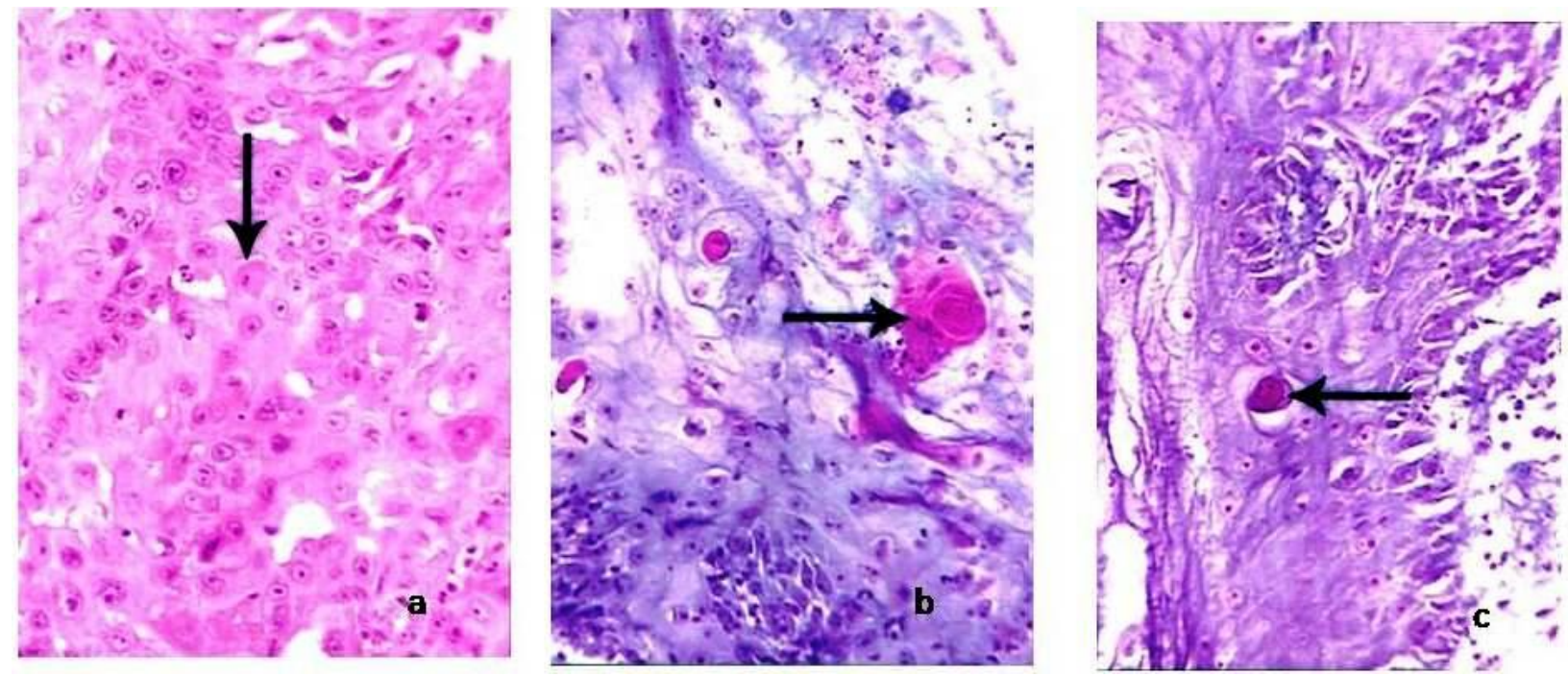

Graph.1 Keratin Pearl staining by hematoxylin and eosin stain and modified Papanicolaou stain and modified Mallory stain in Normal keratinized Epithelium

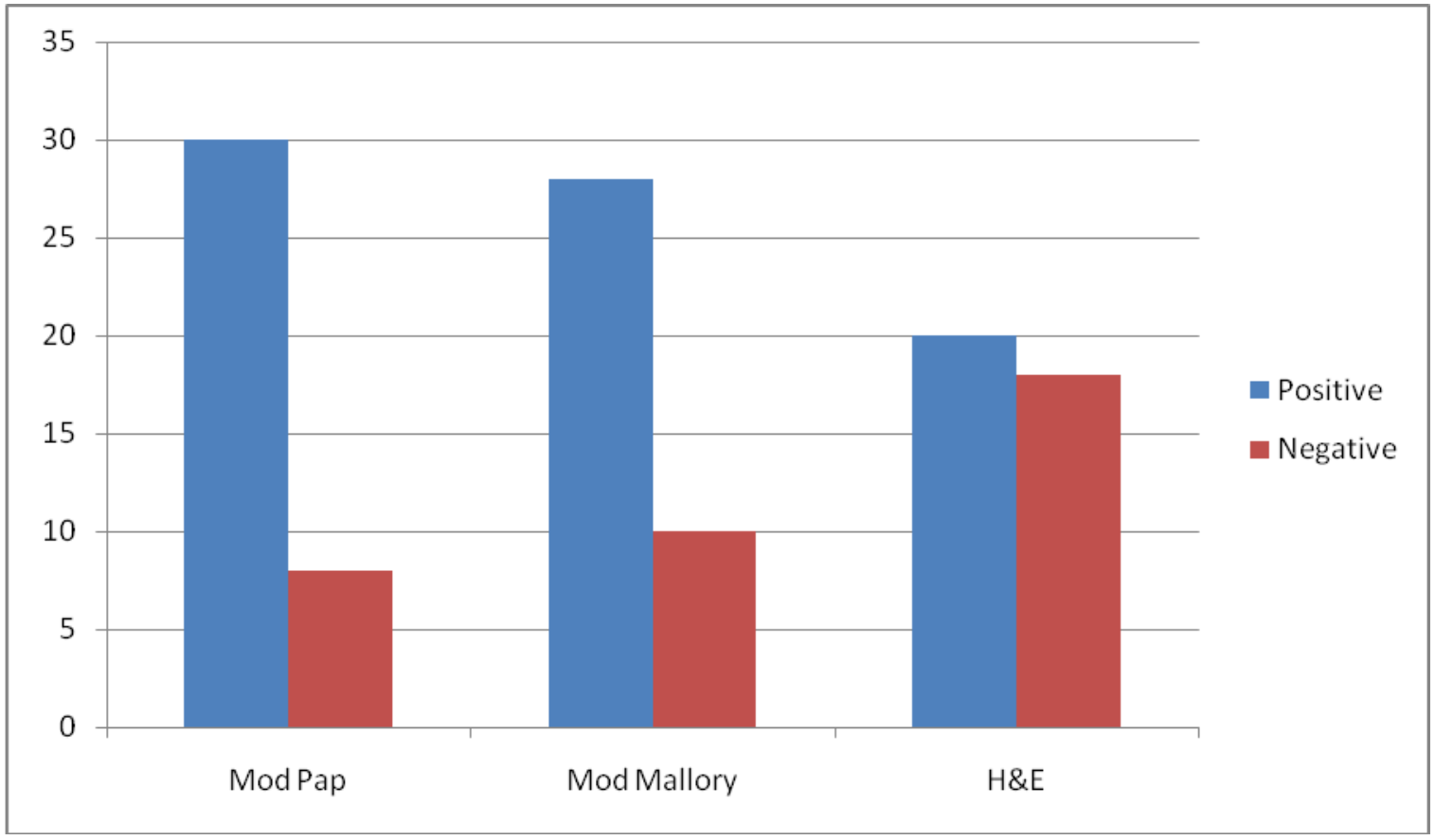


Graph.2 Individual cell Keratin staining by hematoxylin and eosin stain and modified Papanicolaou stain and modified Mallory stain in Normal keratinized Epithelium

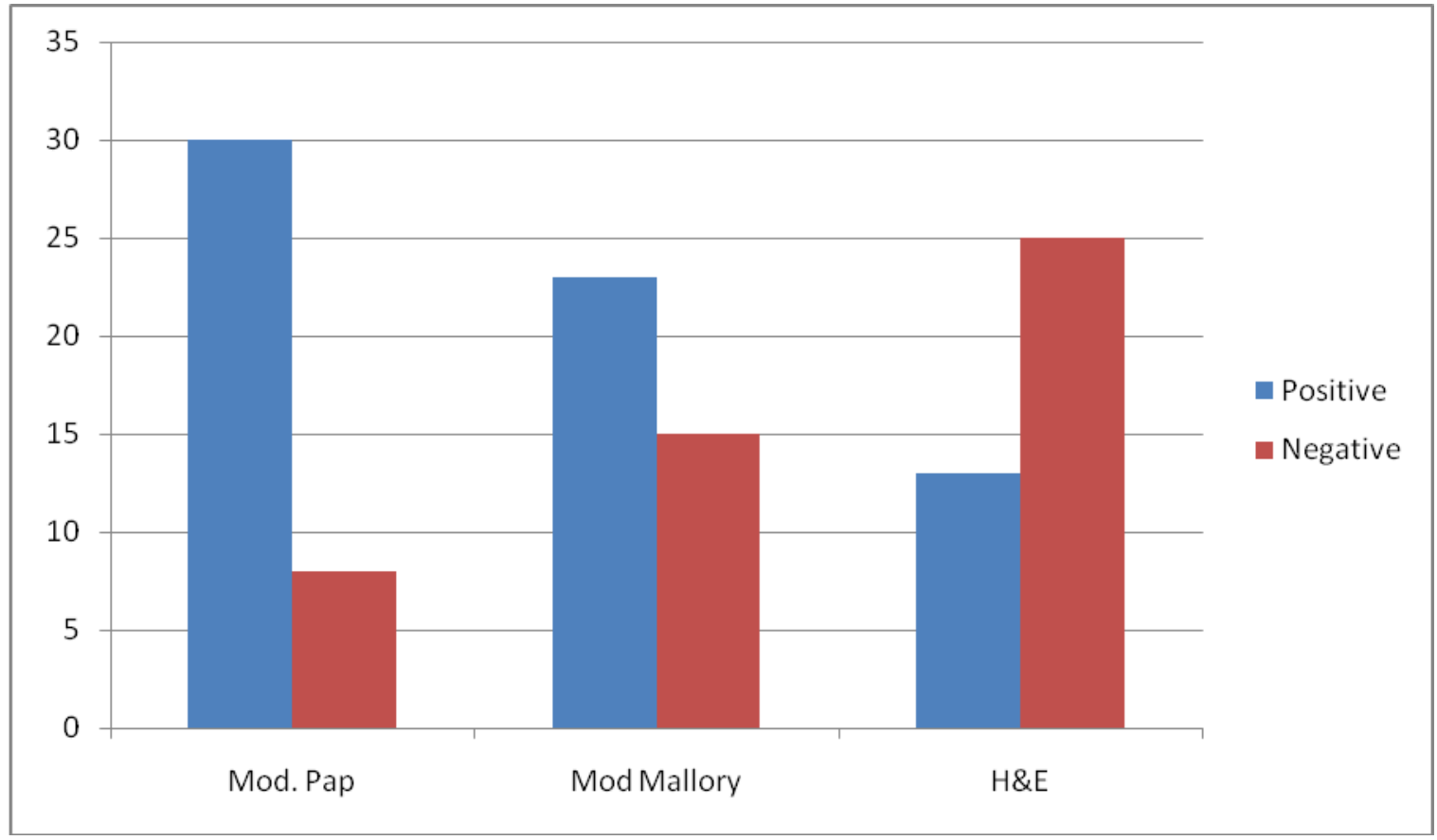

Similar finding of high degree of intensity of staining of keratin in modified Papanicolou stain was reported by Santhosh kumar et al., (2016), Richard Elzay (1983) and Modified Mallory stain was reported by Ayoub-shklar. This concurs with our study.

The individual cell keratinisation was significantly positive at $\mathrm{p}=0.001$ in Modified Papanicolaou stain compared to modified Mallory's stain and $\mathrm{H} \& \mathrm{E}$ stain in oral SCC group. Similar findings were reported in various other studies. This value can be important in identifying differentiation level of squamous cell carcinoma.

There is varying and abnormal level of keratin expression in malignant cells of oral SCC. This different nature of keratin molecule prevailing within the dysplastic cell probably explain the difference in staining quality of modified Papanicolaou stain mainly as well as modified Mallory's stain as shown in our study.
This variation in staining quality depends on degree of variation of keratinisation during the progression of the malignancy.

The Modified Papanicolaou stain has more significant association with demonstration of keratin pearl and individual cell keratinization in well and moderately differentiated squamous cell carcinoma than the routine $\mathrm{H}$ \& E stain. It can be favorably utilized to visualize the keratin pearl and individual cell keratin areas, by doing so the differentiation level of epithelial cells in oral squamous cell carcinoma.

We conclude that the efficacy of distinct identification of KP and ICK in oral SCC by modified PAP stain is better than H\&E stain. But $H \& E$ is gold standard and simple stain in demonstrating other details like nucleus, connective tissue structures. So modified PAP can be used as an adjuvant stain in case of oral SCC along with H\&E stain. 


\section{References}

Ayoub, P., Shklar, G. 1963. A modification of Mallory connective tissue stain as a stain for keratin. Oral Pathol. Oral Surg. Oral Med., 16: 580-581.

Bancroft, D. 2002. John \& Gamble Marilyn Theory and practice of histological techniques, 149-155, 109-123.

Clausen, H., Moe, D., Buschard, K. et al. 1986. Keratin proteins in human oral mucosa. J. Oral Pathol., 15: 36-42.

Coulombe, P.A., Fuchs, E. 1990. Elucidating the early stages of keratin filament assembly. J. Cell Biol., 111: 153-169.

Elzay, R.P. 1983. A modification of the Papanicolaou exfoliative stain to demonstrate keratin in paraffin block tissue sections. Oral Surgery, 56: 51-53.

Harrison, B., Louis, et al. 1999. Head and neck cancer- a multidisciplinary approach, 411-444.

Kumar Vinay, et al. 2004. Pathologic basis of disease, 7th edition, pp271, 780-781, 806-808, 1242.

Nagle, R.B., McDaniel, K.M., Clark, V.A. et al. 1983. The use of antikeratin antibodies in the diagnosis of human neoplasms. Am. J. Clin. Pathol., 79: 458-466.

Neville, B.W., Day, A.T. 2002. Oral cancer and precancerous lesions. Ca Cancer J. Clin., 52: 195-215.
Neville, W., Brad, et al. 2009. Oral \& Maxillofacial pathology, $3^{\text {rd }}$ edition, 409-421.

Parija, U.R. 1991. Site and side distribution in oral cancer-An epidemiological study of 1482 cases in five years. In Oral Oncol., Vol. I. 14-18.

Pindborg, J.J. et al. 1990. Oral cancer epidemiology, etiology and pathology. 46-48, 52-54.

Rothman, S. 1954. Oral pathology-Physiology of keratinisation, 7: 1085-1090.

Santhosh kumar, C., et al. 2016. Comparison of Modified Papanicolaou and Hematoxylin and Eosin Stain in Demonstration of Keratin Pearl and Individual Cell Keratin in Oral Squamous Cell Carcinoma. Int. J. Curr. Microbiol. App. Sci., 5(7): 558-564.

Santhosh kumar, C., et al. 2016. Demonstration and Comparison of Keratin Pearl and Individual Cell Keratin in Oral Squamous Cell Carcinoma using Modified Mallory's Stain and Hematoxylin and Eosin, Int. J. Curr. Microbiol. App. Sci., 5(7): 586591.

Schweizer, J., Winter, H. 1983. Keratin biosynthesis in normal mouse epithelia and in squamous cell carcinomas. $J$. Biol. Chem., 256: 13268-13272.

Shafer, G., William, et al. 1993. Textbook of oral pathology, 4th edition, 112-130.

Tencate, A.R. 1998. Oral Mucosa. 5th edition, 351-362.

\section{How to cite this article:}

Santhosh Kumar Caliaperoumal, Sudhakar Srinivasan, Meer Ahmed Ibrahim Munshi. 2017. Comparison of Staining of Keratin Pearl and Individual Cell Keratin in Oral Squamous Cell Carcinoma by Modified Papanicolaou, Modified Mallory's and Hematoxylin and Eosin Stain. Int.J.Curr.Microbiol.App.Sci. 6(3): 687-693. doi: https://doi.org/10.20546/ijcmas.2017.603.079 